Vol.60: e17160456, January-December 2017 http://dx.doi.org/10.1590/1678-4324-2017160456 ISSN 1678-4324 Online Edition
BRAZILIAN ARCHIVES OF BIOLOGY AND TECHNOLOGY

AN INTERNATIONAL JOURNAL

\title{
Seasonal dynamics and management of whitefly (Bemesia tabaci Genn.) in tomato (Solanum esculentum Mill.)
}

\author{
Devinder Sharma $^{1}$, Asifa Maqbool ${ }^{1}$, Vishav Vir Singh Jamwal ${ }^{\text {* }}$, Kuldeep Srivastava², \\ Ashutosh Sharma ${ }^{3}$. \\ ${ }^{1}$ Sher-e-Kashmir University of Agricultural Sciences and Technology of Jammu - Department of Entomology, \\ Jammu, Jammu and Kashmir, India; ${ }^{2}$ National Research Centre for Litchi, Muzaffarpur, Bihar, India; ${ }^{3}$ DAV \\ University - Department of Agriculture, Sarmastpur, Jalandhar, India.
}

\begin{abstract}
Studies on seasonal dynamics of white fly (Bemesia tabaci) on tomato (Solanum esculentum var. Pusa Ruby) revealed that it appeared first during the $13^{\text {th }}$ and reached maximum during $21^{\text {st }}$ standard meteorological week. A positive correlation between adult population and abiotic factors viz. temperature (maximum and minimum) and sunshine hours was observed, whereas humidity (maximum and minimum) and rainfall showed a negative correlation with it. Taken together, the key weather parameters studied, caused 89.00 per cent variation in whitefly population ( $R^{2}$ value). Combination of carbofuran (soil application) + imidacloprid (seed treatment) + imidacloprid (foliar application) proved significantly superior and caused maximum reduction in whitefly population followed by imidacloprid (seed treatment) + thiomethoxam (spray), imidacloprid (seed treatment) + imidacloprid (spray), imidacloprid (seed treatment) + dimetheoate (spray), carbofuran (soil application) + malathion (spray), and imidacloprid (seed treatment) + yellow sticky traps. The highest cost benefit ratio of 1:25.04 was recorded in case of carbofuran (soil application) + imidacloprid (seed treatment ) + imidacloprid (foliar application) followed by 1:22.38 for imidacloprid (seed treatment) + thiomethoxam (spray) ; 1:21.81 for imidacloprid (seed treatment) + imidacloprid (spray); 1:19.27 imidacloprid (seed treatment) + dimetheoate (spray); 1:19.48 carbofuran (soil application) + malathion (spray), and 1:8.33 for imidacloprid (seed treatment) + yellow sticky traps. The soil application of carbofuran + seed treatment with imidacloprid and three foliar sprays of imidacloprid at fortnight interval starting 40 days after transplanting is found effective and is advised for whitefly management in susceptible tomato cultivars.
\end{abstract}

Key words: Tomato, whitefly, insect pest management

\footnotetext{
*Author for correspondence: jamwal.v.v@gmail.com
} 


\section{INTRODUCTION}

Tomato (Solanum esculentum Mill.) is a popular and widely grown vegetable in the world. Among the various sucking insect-pests, whitefly (Bemesia tabaci Genn.) is one of the destructive pests causing serious damage to tomato crop and is responsible for lowering its yield ${ }^{1}$. The destructive pest status of whiteflies is attributed to a number of factors like high degree of polyphagy, ingestion of phloem sap, massive honey dew secretions (which reduce both the cosmetic value of the tomato and the available leaf area for photosynthesis), uneven ripening and transmission of viruses like Tomato Yellow Leaf Curl Virus ${ }^{2}$. Further, the honeydew (a sweet and sticky substance) is also secreted by the pest which supports the growth of sooty mould which in turn affects the yield in both quantitative and qualitative terms ${ }^{3}$.

The magnitude of crop losses associated with whitefly and its sudden worldwide dissemination generated a keen global interest in all aspects of its biology ${ }^{1}$. Weather factors i.e., temperature, relative humidity and precipitation play a major role in whitefly incidences and its development. It is necessary to record its exact seasonal abundance and its correlation with various weather factors. Since whitefly infestations can easily go unnoticed until they reach high numbers, it is important to minimize potential infestations by employing all possible control tactics prior to chemical control. However, chemical control of whitefly is quite challenging because it also causes mortality of its natural enemies ${ }^{4}$. Further, there are reports of the development of insecticide resistance towards divergent classes of insecticides 5 . Keeping this in view, the present study deals with the population build up of whitefly and its module based management in tomato.

\section{MATERIALS AND METHODS}

The replicated field trials of tomato variety Pusa Ruby were conducted at University Research Farm, Chatha, SKUAST, Jammu. Certified seeds of tomato were sown in raised seed bed nursery. The main field selected for each experiment was ploughed for three times. The seeds were sown under natural conditions without the application of any manure and fertilizer. The plot size was $3 \times 2.5 \mathrm{~m}$. One month old seedlings were transplanted at a distance of $60 \times 45 \mathrm{~cm}$. The experiment was conducted under pesticide free conditions. The occurrence/ incidence of insect pests were recorded from sowing till the harvest. Observations on the population of whitefly were recorded in three leaves from top, middle and bottom of the canopy (one leaf each) from five plants randomly selected. Data on various abiotic parameters viz., maximum and minimum temperature, morning and evening relative humidity, sunshine hours, and rainfall was collected weekly from University Agrometeorology Facility and was subjected to simple correlation and regression studies as given by Senedcor and Cochran $(1967)^{6}$.

Replicated trials were laid out in Randomized Block Design (RBD). All recommended agronomic practices for tomato plants were followed. In order to find out efficiency of the insecticide treatments, the crop thus raised was sprayed with seven treatment combinations including control replicated thrice. The crop was sprayed thrice. Five plants were randomly selected from each plot. Observations were recorded on insect count before the spray and also after 1, 7 and 14 days of spray using a knapsack sprayer. In control plots only water was sprayed. The sprayer was rinsed carefully after each spray. Data thus obtained was statistically analyzed and the efficacy of the insecticides was evaluated. The yield from insecticide treated and control plots were recorded. In order to compute cost/benefit ratio, the yields of control and insecticide treated plots per hectare were worked out. The cost of 
Seasonal dynamics and management of whitefly

insecticides used, labour charges and cultivation charges per hectare were also worked out and the cost/benefit ratio for all the treatments was calculated.

\section{RESULTS AND DISCUSSION}

\section{Seasonal incidence}

The whiteflies were first noticed during $14^{\text {th }}$ standard meteorological week (SMW) and increased gradually upto $21^{\text {st }}$ SMW (Figure 1) during summer months. The findings were in agreement with Parmar et al. $(2013)^{7}$, however in contrary to this, Shahnaz et al. (2006) $)^{8}$ reported that B. tabaci was prevalent both in summers and winters with a higher pest incidence in winters. This could be due to the differences in time of sowing and prevalent climatic conditions. The peak period of whitefly population is suitable for maximum degree of control by manipulation of agronomic practices and use of chemicals ${ }^{9}$. The correlation studies between whitefly population and various abiotic factors showed a significant (Pearson correlation $r$, at $p \leq 0.05$ ) positive correlation with temperature (both maximum and minimum) and a positive but non-significant correlation with sunshine hours. Whereas a significant negative correlation was observed with relative humidity (maximum and minimum) and a negative, but non-significant correlation was observed with rainfall (Table 1). The multiple linear regression analysis showed that all the weather parameters studied, taken together were responsible for $89 \%\left(\mathrm{R}^{2}\right.$ value) of total change in whitefly population (Table 2). Weather parameters played a key role in the development of whitefly (B. tabaci) population on tomato. The results of the present study were in accordance with Ashfaq et al. (2010) and Kaur et al. (2010) ${ }^{10-11}$ who also reported that the whitefly population was positively correlated with mean temperature and negatively correlated with mean relative humidity. The positive correlation between the temperature and whitefly population can be attributed to the enhanced rate of development and reproduction of whitefly. The relatively higher temperatures can be conducive for rapid multiplication and activity of B. tabaci.

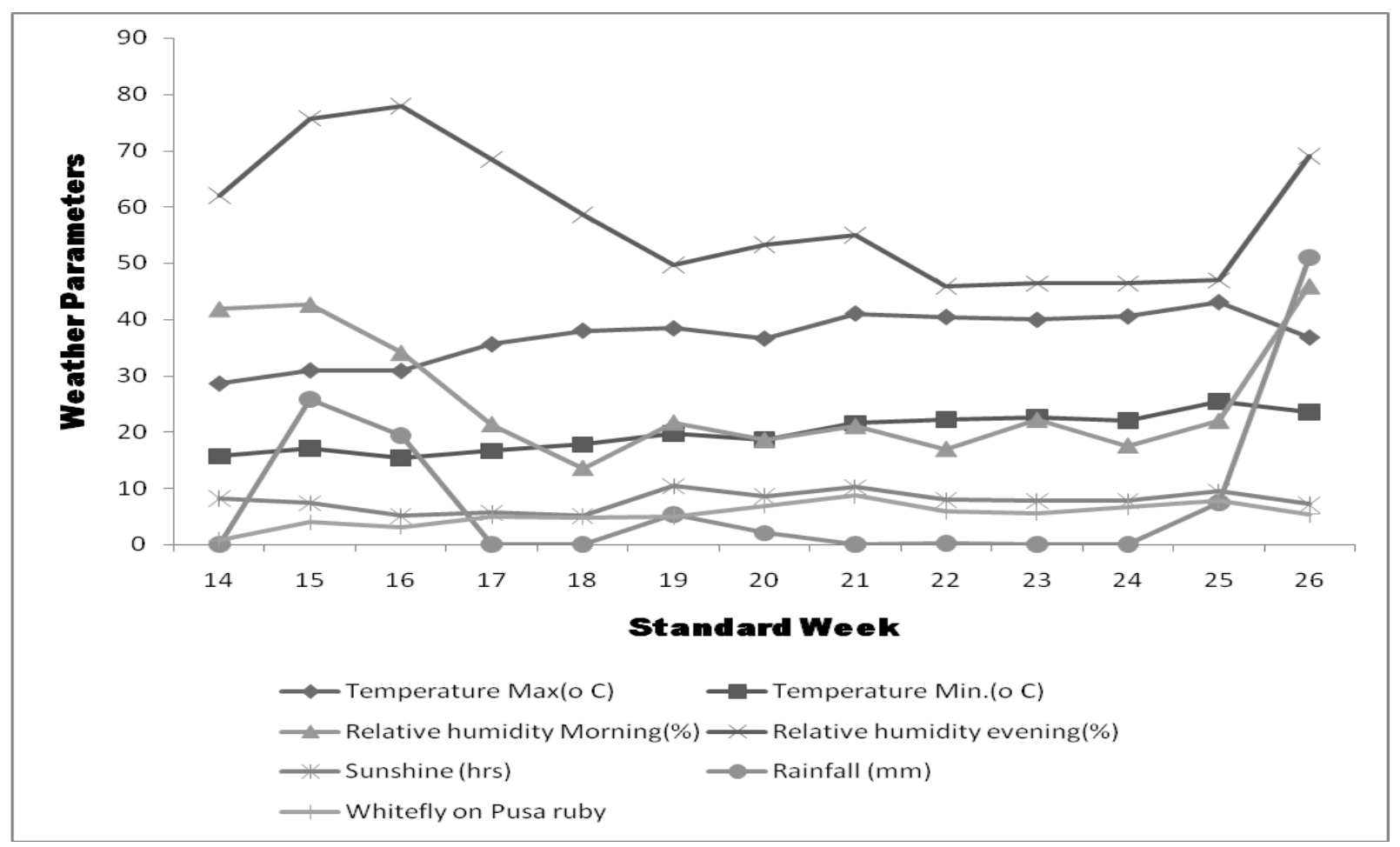

Fig 1: Whitefly per plant in relation to weather parameters on tomato cv. Pusa ruby. 
Table 1. Correlation of insect pests with weather parameters on tomato cv. Pusa Ruby

\begin{tabular}{|c|c|c|c|c|c|c|}
\hline \multirow[t]{2}{*}{ Insect pests } & \multicolumn{2}{|c|}{ Temperature $\left({ }^{\circ} \mathrm{C}\right)$} & \multicolumn{2}{|c|}{ Relative humidity (\%) } & \multirow{2}{*}{$\begin{array}{c}\text { Rainfall } \\
\text { mm }\end{array}$} & \multirow{2}{*}{$\begin{array}{c}\text { Sunshine } \\
\text { hours }\end{array}$} \\
\hline & Maximum & Minimum & Maximum & Minimum & & \\
\hline \multicolumn{7}{|l|}{ Whitefly } \\
\hline & $0.803 * *$ & $0.764 * *$ & $-0.683 *$ & $-0.669 *$ & -0.028 & 0.450 \\
\hline
\end{tabular}

Table 2. Multiple regression equation of insect pests with weather parameters

Insect pests

Regression equation

$$
\mathrm{Y}_{1}=17.084-0.941 \mathrm{X}_{1}-1.397 \mathrm{X}_{2}-0.546 \mathrm{X}_{3}+0.273 \mathrm{X}_{4}+0.247 \mathrm{X}_{5}+0.339 \mathrm{X}_{6} \quad 0.890 * *
$$

Whitefly

$\mathrm{Y}_{\mathrm{I}}=$ Whitefly per plant; $\mathrm{X}_{1}=$ Maximum temperature $\left({ }^{\circ} \mathrm{C}\right) ; \mathrm{X}_{2}=$ Minimum temperature $\left({ }^{\circ} \mathrm{C}\right) ; \mathrm{X}_{3}=$ Maximum relative humidity (\%); $\mathrm{X}_{4}=$ Minimum relative humidity $(\%) ; \mathrm{X}_{5}=$ Rainfall $(\mathrm{mm}) ; \mathrm{X}_{6}=$ Sunshine hours

* Significant at 5 per cent probability level

** Significant at 1 per cent probability level

Correlation between meteorological parameters and whitefly population was negatively correlated with number of rainy days and total rainfall as also reported by Kaur et al., (2010) and Anzola and Lastra (2008) ${ }^{11-12}$. This may be attributed to the destruction of eggs, nymphs and pupae of whitefly during continuous rains. The time intervals over which rainfall was associated with reduction in $\mathrm{B}$. tabaci populations can be interruptive in terms of length of the insect's life cycle. With a development of 3 weeks (i.e. time from egg to adult) and the reduction in adult field counts suggested that rains may suppress oviposition, increase the mortality of nymphs, adults and induce insect emigration. Cooler weather, high relative humidity and rainfall can therefore be detrimental to whitefly population and its spread. Hence a strategy should be planned to minimize the pest and disease attack either by manipulation in agronomic practices.

\section{Management of whitefly}

The results revealed that seed treatment with imidacloprid followed by soil application of carbofuran and imidacloprid spray was the highly effective among all the treatments producing highest crop yield, reduction of whitefly infestation in tomato (Table 3; Figure 2). Prophylactic soil application of carbofuran and/or sprays of insecticides lowered populations of whiteflies to varying extents; and increased crop yield ${ }^{13}$. Gosh and Khan $(2010)^{14}$ recorded maximum control of whitefly with mixture of various insecticides. The bio-efficacy of imidacloprid as a seed dresser against sucking pest of okra was found to be promising against whitefly ${ }^{15}$. Management of whitefly of tomato with the use of insecticides as seed treatment provided an opportunity to minimise the quantity of the insecticide. The order of efficacy of other treatment combination was imidacloprid (seed treatment) + imidacloprid (spray) > imidacloprid (seed treatment) + thiamethoxam (spray) $>$ imidacloprid (seed treatment) + dimetheoate (spray) $>$ carbofuran (soil application) + malathion (spray) $>$ imidacloprid (seed treatment) + yellow sticky traps.

Both thiamethoxam and imidacloprid are new broad spectrum neonicotinoids ${ }^{16}$ with high insecticidal activity against sucking insects proved effective in management of whiteflies. Neonicotinoids is a class of neuro-active insectides that act by insect nicotinic acetylcholine receptors ${ }^{17}$. Our observations are in conformity to the earlier findings of Mandal and Mandal (2010) and Dubey and Singh (2010) ${ }^{18-19}$ who also 
reported that imidacloprid and thiamethoxam were significantly superior in efficacy against sucking insect pests. Patel et al. (2010) ${ }^{20}$ also reported that imidacloprid 200 SL and thiamethoxam 25 WG were effective to suppress the whitefly population. Dimetheoate and malathion in combination with other insecticides also proved effective in reducing the whitefly population. Borah and Nath $(1995)^{21}$ reported that the application of dimetheoate @ $0.03 \%$ at 15 and 30 days after germination significantly reduced the white flies population and significantly lowest incidence of yellow vein mosaic, followed by dimetheoate $0.03 \%$ at 15 days after germination + malathion $0.05 \%$ at 25 and 30 days after germination as well as malathion $0.05 \%$ at 15 days after germination + dimetheoate $0.03 \%$ at 25 and 30 days after germination. Combination of imidacloprid (Seed treatment) + yellow sticky traps was also effective in suppressing the whitefly population. Moreau and Isman (2011) ${ }^{22}$ also reported that yellow sticky traps were effective at trapping adult whiteflies and significantly reduced adult populations on the main crops (peppers) compared with the control.

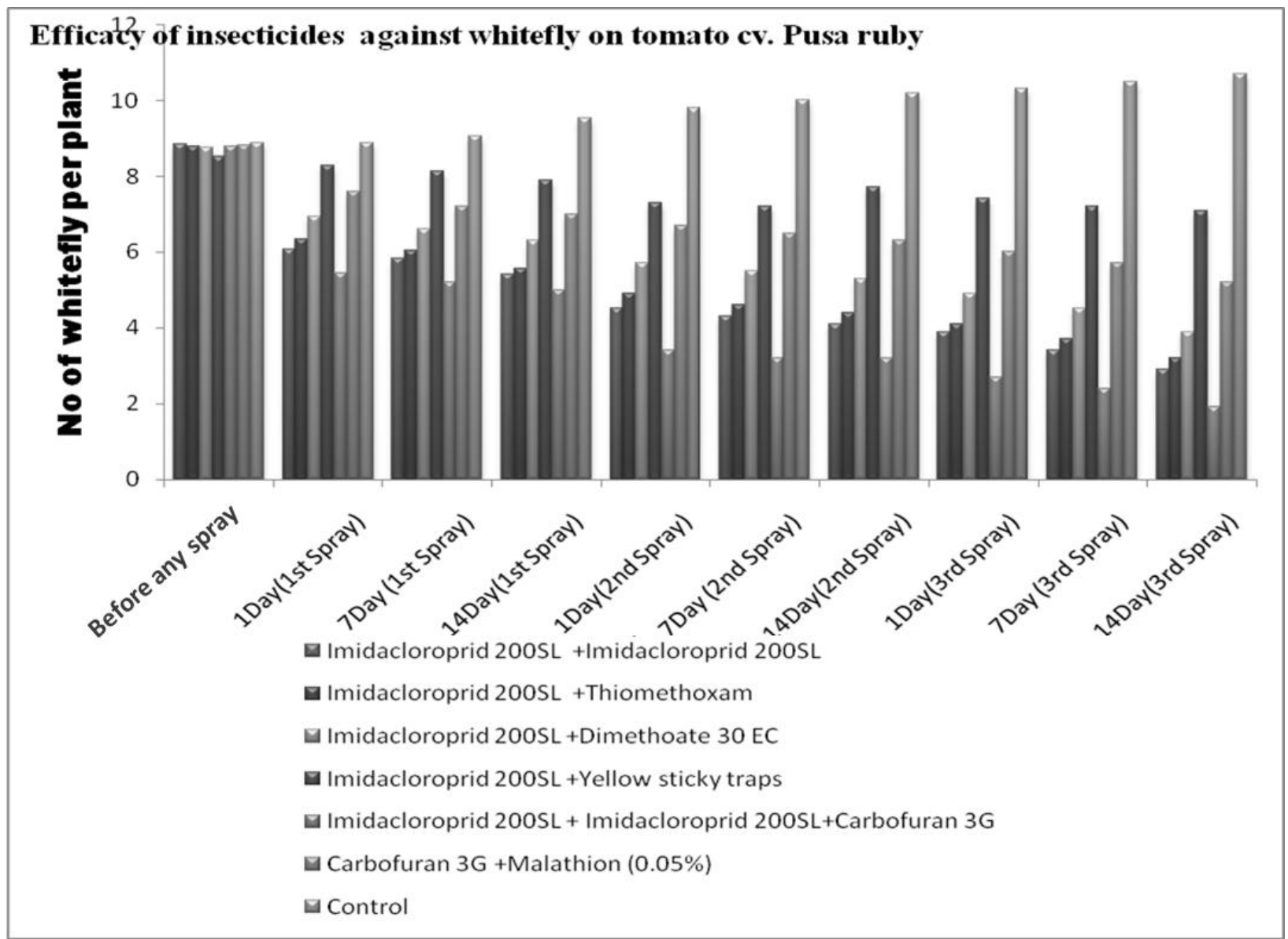

Fig 2: Efficacy of insecticides against whitefly on tomato cv. Pusa ruby. 
Table 3: Efficacy of treatment combinations against whitefly on Tomato cv. Pusa Ruby

\begin{tabular}{|c|c|c|c|c|c|c|c|c|c|c|c|}
\hline \multirow{2}{*}{ Treatments } & \multirow{2}{*}{$\begin{array}{l}\text { Pre- } \\
\text { count }\end{array}$} & \multicolumn{3}{|c|}{ 1st Spray (40DAT) } & \multicolumn{3}{|c|}{$2^{\text {nd }}$ Spray (55 DAT) } & \multicolumn{3}{|c|}{$3^{\text {rd }} \operatorname{Spray}(70$ DAT $)$} & \multirow{2}{*}{$\begin{array}{c}\text { Cost } \\
\text { benefit } \\
\text { ratio }\end{array}$} \\
\hline & & 1Day & 7Day & 14Day & 1Day & 7Day & 14Day & 1Day & 7Day & 14Day & \\
\hline $\begin{array}{l}\text { Imidacloprid } 200 \mathrm{SL}(\mathrm{St}) \\
\text { Imidacloprid } 200 \mathrm{SL}(\mathrm{Sp})\end{array}$ & 8.85 & $6.067 \pm 0.088$ & $5.833 \pm 0.088$ & $5.400 \pm 0.115$ & $4.533 \pm 0.203$ & $4.333 \pm 0.088$ & $4.133 \pm 0.088$ & $3.933 \pm 0.086$ & $3.433 \pm 0.117$ & $2.933 \pm 0.120$ & $1: 22.38$ \\
\hline $\begin{array}{l}\text { Imidacloprid 200SL(St) }+ \\
\text { Thiomethoxam } 25 \text { WG(St) }\end{array}$ & 8.78 & $6.333 \pm 0.088$ & $6.033 \pm 0.088$ & $5.567 \pm 0.176$ & $4.933 \pm 0.448$ & $4.600 \pm 0.153$ & $4.433 \pm 0.088$ & $4.067 \pm 0.088$ & $3.733 \pm 0.086$ & $3.200 \pm 0.058$ & $1: 21.81$ \\
\hline $\begin{array}{l}\text { Imidacloprid 200SL (St) + } \\
\text { Dimetheoate } 30 \text { EC(Sp0 }\end{array}$ & 8.76 & $6.933 \pm 0.033$ & $6.600 \pm 0.058$ & $6.300 \pm 0.153$ & $5.667 \pm 0.088$ & $5.500 \pm 0.058$ & $5.200 \pm 0.058$ & $4.933 \pm 0.120$ & $4.533 \pm 0.203$ & $3.900 \pm 0.115$ & $1: 19.27$ \\
\hline $\begin{array}{l}\text { Imidacloprid 200SL(St) }+ \\
\text { Yellow sticky traps }\end{array}$ & 8.52 & $8.267 \pm 0.120$ & $8.133 \pm 0.088$ & $7.900 \pm 0.115$ & $7.300 \pm 0.115$ & $7.200 \pm 0.058$ & $7.733 \pm 0.120$ & $7.400 \pm 0.058$ & $7.233 \pm 0.289$ & $7.100 \pm 0.145$ & $1: 8.333$ \\
\hline $\begin{array}{lll}\text { Imidacloprid } & \text { 200SL(St) } & + \\
\text { Imidacloprid } & \text { 200SL(Sp) } & + \\
\text { Carbofuran 3G } & \end{array}$ & 8.79 & $5.433 \pm 0.145$ & $5.200 \pm 0.058$ & $5.000 \pm 0.058$ & $3.400 \pm 0.173$ & $3.200 \pm 0.058$ & $3.167 \pm 0.120$ & $2.700 \pm 0.115$ & $2.367 \pm 0.176$ & $1.933 \pm 0.120$ & $1: 25.04$ \\
\hline $\begin{array}{lcc}\text { Carbofuran } & \text { 3G(St) } \\
\text { Malathion(Sp) } & (\mathbf{0 . 0 5 \%}) & + \\
\end{array}$ & 8.83 & $7.600 \pm 0.153$ & $7.200 \pm 0.058$ & $7.000 \pm 0.058$ & $6.700 \pm 0.231$ & $6.467 \pm 0.120$ & $6.333 \pm 0.145$ & $6.000 \pm 0.058$ & $5.733 \pm 0.088$ & $5.167 \pm 0.120$ & $1: 19.48$ \\
\hline Control & 8.87 & $8.870 \pm 0.115$ & $9.067 \pm 0.088$ & $9.533 \pm 0.145$ & $9.870 \pm 0.010$ & $10.00 \pm 0.058$ & $10.167 \pm 0.145$ & $10.267 \pm 0.08$ & $10.46 \pm 0.088$ & $10.70 \pm 0.115$ & - \\
\hline$C D(p=0.05) \pm S . E$ & & $\mathbf{0 . 3 6 2} \pm 0.164$ & $\mathbf{0 . 2 5 3} \pm 0.115$ & $\mathbf{0 . 4 1 7} \pm 0.189$ & $\mathbf{0 . 5 3 9} \pm 0.245$ & $\mathbf{0 . 3 0 4} \pm 0.138$ & $\mathbf{0 . 3 5 6} \pm 0.162$ & $\mathbf{0 . 2 6 8} \pm 0.112$ & $0.404 \pm 0.184$ & $\mathbf{0 . 3 4 9} \pm 0.158$ & \\
\hline
\end{tabular}


All the treatment combinations used in the study reduced the whitefly population significantly and in turn enhanced the yield. Combination of imidacloprid and carbofuran with B:C ratio of 1:25.04 was found statistically superior over rest of the treatments followed by combination of imidacloprid and imidacloprid 1:22.38, imidacloprid and thiamethoxam 1:19.2, combination of imidacloprid and dimetheoate 1:21.81, carbofuran and malathion 1:19.48, imidacloprid 1:19.27 and imidacloprid and yellow sticky traps 1:8.33 (Table 2).

Yellow sticky traps are useful methods for monitoring and early detection of whiteflies and documentation of relative whitefly abundance over time. Results of monitoring efforts provide documentation on the need for and success of suppression efforts applied. Due to their systemic action ${ }^{16}$, thiamethoxam and imidacloprid was accepted by farmers and also had occupied prime position in IPM programmes. Such compounds which are systemic and potential can be used in developing sound pest management strategy to achieve the desired level of control.

\section{CONCLUSION}

The present investigation indicated the possibility of using imidacloprid (seed treatment) followed by soil application of carbofuran and imidacloprid spray against whitefly and maximizing the yield in IPM programme of tomato crop in the absence of any resistant/tolerant cultivars.

\section{ACKNOWLEDGEMENTS}

We thank Professor and Head, Division of Entomology, SKUAST-Jammu for his help.

\section{REFERENCES}

1. De Barro PJ, Liu SS, Boykin LM, Dinsdale AB. Bemisia tabaci: a statement of species status. Annu Rev Entomol. 2011; 56:1-9.

2. Brown JK, Czosnek H. Whitefly transmission of plant viruses. Adv. Bot. Res. 2002 Dec $31 ; 36: 65-100$.

3. Oliveira MR, Henneberry TJ, Anderson P. History, current status, and collaborative research projects for Bemisia tabaci. Crop Prot. 2001; 20(9):709-23.

4. Michaud JP, McKenzie CL. Safety of a novel insecticide, sucrose octanoate, to beneficial insects in Florida citrus. Fla Entomol. 2004; 87(1):6-9.

5. Denholm I, Devine GJ, Gorman K, Horowitz AR. Insecticide resistance in Bemisia: a global perspective. In Annals of the $3^{\text {rd }}$ International Bemisia Workshop. 2003; p 113.

6. Snedecor GW, Cochran WG. Statistical methods,(Iowa State University Press, Ames, Iowa, USA). 1967; pp650.

7. Parmar KD, Korat DM, Joshi MN, Patel AR, Shah PG. Relative bio-efficacy of insecticides/miticides against pest complex of okra. Karnataka J agric Sci. 2013; 26(3):375-8.

8. Shahnaz E, Kumar K, Razdan VK, Tewari AK, Singh B. Host Range and Seasonal Incidence of Tomato Leaf Curl Disease in Sub-tropics of Jammu. Environ. Ecol. 2006; 24:302-5.

9. Sitaramaraju S, Prasad NV, Krishnaiah PV. Seasonal incidence of sucking insect pests on Bt cotton in relation to weather parameters. Ann Plant Protect Sci. 2010; 18(1):49-52.

10. Ashfaq M, Noor-ul-Ane M, Zia K, Nasreen A. The correlation of abiotic factors and physico-morphic charateristics of (Bacillus thuringiensis) Bt transgenic cotton with whitefly, Bemisia tabaci (Homoptera: Aleyrodidae) and jassid, Amrasca devastans (Homoptera: Jassidae) populations. Afr. J. Agric. Res. 2010; 5(22):3102-7. 
11. Kaur L, Gill KK, Cheema HK, Dhaliwal LK, Sirari A, Kingra PK. Meteorological factors attributing yellow mosaic virus severity on greengram. Indian J Agric Sci. 2010; 80(11):1007-9.

12. Anzola D, Lastra R. Whiteflies population and its impact on the incidence of Tomato yellow mosaic virus in Venezuela. J Phytopathol. 1985; 112(4):363-6.

13. Karungi J, Agamire P, Kovach J, Kyamanywa S. Cover cropping and novel pesticide usage in the management of pests of hot pepper (Capsicum chinense). Int J Trop Insect Sci. 2010; 30(02):84-92.

14. Ghosh S, Khan MR. Integrated approach for management of major Insect pests and Nematode problems of Okra, Abelmoschus esculentus (L.). Ann Plant Protect Sci. 2010; 18(2):388-93.

15. Lal KM, Singh SP, Kumari K, Singh SN. Bio-efficacy of Beta-cyfluthrin, Lambdacyhalothrin and imidacloprid against Earias vitella Fab. in Okra. Ann Plant Protect Sci. 2008; 16(1):21-4.

16. Prabhaker N, Castle SJ, Naranjo SE, Toscano NC, Morse JG. Compatibility of two systemic neonicotinoids, imidacloprid and thiamethoxam, with various natural enemies of agricultural pests. J. Econ. Entomol. 2011; 104(3):773-81.

17. Matsuda K, Buckingham SD, Kleier D, Rauh JJ, Grauso M, Sattelle DB. Neonicotinoids: insecticides acting on insect nicotinic acetylcholine receptors. Trends Pharmacol. Sci. 2001; 22(11):573-80.

18. Mandal SK, Mandal RK. Comparative efficacy of Insecticides against Mustard aphid, Upaphis erysimi Kalt. Ann Plant Protect Sci. 2010; 18(2):333-5.

19. Dubey SC, Singh B. Seed treatment and foliar application of insecticides and fungicides for management of cercospora leaf spots and yellow mosaic of mungbean (Vigna radiata). Int J Pest Manage. 2010; 56(4):309-14.

20. Patel Y, Sharma HB, Das SB. Novel insecticides for management of whitefly, Bemisia tabaci (Genn.) in cotton. Ann Plant Protect Sci. 2010; 18(1):6-9.

21. Borah RK, Nath PD. Evaluation of an insecticide schedule on the incidence of white fly, Bemisia tabaci (Genn.) and yellow vein mosaic in okra. Indian J Virol. 1995; 11(2):65-7.

22. Moreau TL, Isman MB. Trapping whiteflies? A comparison of greenhouse whitefly (Trialeurodes vaporariorum) responses to trap crops and yellow sticky traps. Pest Manag Sci. 2011; 67(4):408-13. 